\title{
Earnings Management to Avoid Earnings Boosts ${ }^{1}$
}

\section{Naser Makarem and Clare Roberts}

\begin{abstract}
Purpose: The purpose of this study is to investigate whether earnings boosts before the yearend trigger earnings management. It examines whether firms that substantially outperformed their last year earnings during the first three quarters push their earnings down to avoid reporting earnings boosts.
\end{abstract}

Design/Methodology/Approach: Regression analysis is used to compare earnings management of firms with earnings boosts and other firms.

Findings: The results indicate that firms outperforming their last year results by the end of the third quarter manipulate their earnings downwards by means of real activities manipulation, while they do not indicate income-decreasing accruals management. It is also found that, consistent with the prominent shift from accruals management to real activities manipulation, accruals management is more costly which justifies why real activities manipulation is used for downward manipulation.

Research limitations/implications: The results are limited to one single earnings benchmark i.e. last year earnings. Further research may individually or collectively examine other benchmarks including analysts' forecasts.

Implications: The findings suggest that users should be more vigilant of firms exceeding their last year interim results as they could be involved in downward earnings management.

\footnotetext{
${ }^{1}$ This article is $\odot$ Emerald Publishing and permission has been granted for this version to appear here. Emerald does not grant permission for this article to be further copied/distributed or hosted elsewhere without the express permission from Emerald Publishing Limited.
} 
Originality: This study documents earnings management in a new setting where earnings boosts before the year-end trigger downward manipulation.

\section{Keywords}

Earnings Management, Real Activities Manipulation, Accruals Management, Quarterly Earnings

Jel classification: M41

\section{Introduction}

There is extant evidence that managers manipulate earnings. The opportunity to manipulate earnings is twofold: the first is to manipulate financial reports using accounting techniques (accruals management, hereafter AM) and the second is to manipulate underlying transactions (real activities manipulation, hereafter RAM). While an overwhelming majority of prior studies have focused on income-increasing earnings management (e.g. Teoh et al., 1998 a, b; Louis, 2004; Das et al., 2009; Marquardt and Wiedman, 2004; Burgstahler and Eames, 2006; Payne and Robb, 2000) while downward earnings management could also be value-destroying. For instance, downward activities manipulation could lead to the consumption of excessive prerequisites or unnecessary increases in other discretionary expenses. It may also encourage underproduction which in turn results in failure to produce sufficient inventory to meet future demand. All these can affect future performance rather than simply transferring earnings to the future periods. 
The present study investigates earnings management by firms outperforming their last year earnings in order to avoid reporting earnings boosts. Data includes all the US firms between 2002 and 2011 with sufficient quarterly data. Regression analysis is used to compare earnings management of firms with earnings boosts and other firms. As earnings manipulation is more likely to occur towards the year-end (e.g. see Jackson and Wilcox, 2000; Kerstein and Rai, 2007; Jacob and Jorgensen, 2007; Cohen et al., 2010), earnings for the first three quarters could arguably be a fair measure of pre-managed earnings. Accordingly, this study compares firms substantially exceeding their last year earnings by the end of the third quarter (the suspects) to others in terms of their earnings management behaviour. Considering the prominent shift from AM to RAM, it is expected that RAM rather than AM is used by the suspects. The findings are in support of this expectation. This is also consistent with the shift from AM to RAM documented by Cohen et al. (2008). These findings are then explained by examining the costs of earnings management providing evidence that $\mathrm{AM}$ is costlier to the suspects than RAM.

This study contributes to the accounting literature in a number of ways. First, although downward earnings management induced by management changes (e.g. Moore, 1973), employee stock options (e.g. Baker et al., 2003; Coles et al., 2006; Francis et al., 2016), CEO stock options (McAnally et al., 2008), insider purchases (Sawicki and Shrestha, 2008), labor negotiations (Mora and Sabater, 2008), stock repurchases (e.g. Gong et al., 2008), earnings reversals (Das et al., 2009), government subsidies (Jiang et al., 2018), high political costs (McDonnell et al., 2019) has been documented by prior studies, this study provides evidence of income-decreasing earnings management by firms exceeding their last year earnings by the end of the third quarter. We hypothesize and find evidence that the suspect firms engage in income-decreasing manipulation of activities. There is evidence that upward earnings management to achieve earnings benchmarks has declined after the passing of the Sarbanes- 
Oxley Act in 2002 (see Koh et al., 2008). This has downplayed the role of earnings benchmarks in detecting earnings management. However, this study indicates that downward earnings management by firms exceeding benchmarks is commonplace which suggests that earnings benchmarks (particularly last year earnings) are still important signposts for identifying opportunities for earnings management. Hence, users including shareholders, auditors and regulators should be more vigilant of firms exceeding their last year interim results as they could be involved in downward earnings management. Second, this study contributes to the existing evidence on the tradeoff between AM and RAM the post-Enron era. Consistent with the prominent shift from AM to RAM (Cohen et al., 2008; Chan et al., 2015), we show that firms use RAM, not AM, for managing their earnings downwards. Examining the costs of AM and RAM, we further contribute to the current literature by showing that RAM is less costly than AM for downward manipulation which justifies why we observe RAM by downward manipulators. Third, this study introduces an unprecedented ex-ante approach to select firms suspected of earnings management. We employ prior evidence that RAM occurs towards the end of the fiscal year (e.g. Jackson and Wilcox, 2000; Brown and Pinello, 2007; Das et al., 2009; Zang, 2012; Shon and Yan, 2015) to select the suspect firms. As such, unlike most previous studies (e.g. Peasnel et al., 2005; Barua et al., 2006; Tucker and Zarowin, 2006; Roychowdhury, 2006; Francis et al., 2016) that take an expost approach and use earnings after expected manipulation to identify firms suspected of earnings manipulation, this study introduces an ex-ante approach and uses earnings before expected manipulation to do so. The ubiquitous ex-post approach is subject to a backing-out problem (Kang and Sivaramakrishnan, 1995; Lim and Lustgarten, 2002; and Peasnell et al., 2005) because it uses pre-managed earnings, defined as the difference between reported earnings and a measure of earnings management, as a proxy for earnings before expected manipulation. This means that any error in estimation of the earnings management measure 
would lead to a similar error in calculation of pre-managed earnings and hence results in invalid inferences. This study, instead, uses cumulated earnings by the end of the third quarter as earnings before expected manipulation which is not subject to the backing-out problem. This research design for selecting suspect firms is unique in the earnings management literature. Fourth, this is the first study to compare profit and loss firms when income-decreasing earnings management is expected. We suggest that in contexts where downward manipulation is expected, loss-making and profitable firms should be separately analyzed since their earnings management behaviour could be different.

The rest of this article is structured as follows. First, a background review of prior studies is provided followed by the research hypotheses. Then the research methodology including the sample, variable measurement and empirical model are explained. Next, the results of descriptive and multivariate analysis are provided. Finally concluding remarks and future research avenues are drawn out.

\section{Background and Hypotheses}

Agency theory is the standard approach that accounting scholars adopt to research earnings management (Walker, 2013). The theory has long been used to explain the potential information asymmetry in financial reporting and its implications for the main stakeholders of entities. Agency theory predicts that managers manipulate their earnings to maximize their interests. This interest maximization could require downward manipulation of earnings. For instance, Healy (1985) shows that, in addition to income-increasing earnings management, managers engage in income-decreasing manipulation in order to maximize their bonuses. There are various incentives for managers to prefer lower earnings including to avoid political costs (e.g. Watts and Zimmerman, 1986; Monem, 2003), to secure managers' job 
(e.g. Fudenberg and Tirole, 1995) and to avoid higher expectations for the future (DeGeorge et al., 1999).

According to prospect theory, to evaluate a firm's performance, users of financial statements rely on earnings benchmarks instead of absolute value of earnings (Kahneman and Tversky, 1979). Performance benchmarks are usually in the form of earnings thresholds. As DeGeorge et al. (1999) point out, the importance of earnings-related benchmarks to managers is due to the emphasis those who are interested in firms' performance, including board of directors, investors, and analysts, or in firms' viability including customers, suppliers, bankers and employees, place on meeting benchmarks. They refer to this tendency to meet benchmarks as "threshold mentality". Empirical evidence supports the importance of beating performance benchmarks. For instance, DeAngelo et al. (1996) report that the market negatively reacts to firms that break a pattern of earnings growth. Firms with a broken pattern of earnings growth experience about $14 \%$ negative abnormal return in the year of earnings decline and do not show a positive abnormal return over three years after the decline. Barth et al. (1999) document a significant decrease in price-to-earnings ratio when a prior pattern of earnings growth is broken. A survey by Graham et al. (2005) reveals that the primary objectives of managers for meeting earnings benchmarks are to improve stock prices and to increase their own reputation.

There is extensive evidence on earnings management to meet earnings targets (e.g. Burgstahler and Dichev, 1997; Burgstahler and Eames, 2006; Daske et al., 2006; Gunny, 2010; Das et al., 2009) as well as other performance targets including current ratios (Dyreng et al., 2017) and bank capital ratios (Orozco and Rubio, 2018). Benchmark beating earnings management can result in downward manipulation. As Peasnell et al. (2005) point out, managers are not willing to report large profits since they are concerned that this will lead to 
increased earnings targets in the future and shifting positive earnings to future periods can make it easier to meet future earnings targets. Prior research also suggests that managers prefer smooth earnings, overstating in bad times and saving for the future in good times (Watts and Zimmerman, 1986; Fudenberg and Tirole, 1995; DeFond and Park, 1997; Peasnell et al., 2005) since volatile earnings are perceived as risky and make future earnings less predictable (e.g. Graham et al., 2005). The tendency to report smooth earnings suggests that if before the year-end earnings are above the expected target, managers have incentives to push them down to avoid reporting a large increase in their reported earnings. Therefore, firms with earnings boosts (the suspects) are expected to manager their earnings downwards. This leads to the first research hypothesis:

H1: Firms with earnings boosts exhibit income-decreasing real activities manipulation.

There is evidence of a shift from AM to RAM in the post-Enron era, which suggests that the suspects may not use AM. If accruals are not managed, then a statistical artefact without manipulation could result in the suspects reporting higher abnormal accruals. This is because the suspects are those with substantial earnings growth, which in turn leads to higher total accruals. Considering the direct relationship between total and abnormal accruals, this would result in higher abnormal accruals. Therefore, the suspects are expected to have higher discretionary accruals which forms the second hypothesis:

H2: Firms with earnings boosts exhibit income-increasing discretionary accruals.

\section{Research Methodology}

\subsection{Sample}


Taking into consideration the approach taken by this study to select suspect firm-years and the need for quarterly information, the sample is selected from the US listed firms because they are obliged to report quarterly financial statements. Data is collected from DataStream and includes all the US firms between 2002 and 2011 with sufficient quarterly data ${ }^{2}$. Firms operating in regulated industries (SIC codes 4400-4999) and banks and financial institutions (SIC codes 6000-6499) are excluded from the sample as they have different incentives for financial reporting compared to firms in other industries (Matsumoto, 2002). The models for earnings management are run cross-sectionally for every year and industry, where industries are identified by two-digit SIC codes. Running the regressions by industries can potentially reduce the effect of possible seasonality as it is expected that firms operating in the same industry are similarly affected by the impact of any potential seasonality. ${ }^{3}$ A minimum of 15 observations is required for each industry-year group and industry-years with fewer observations are removed. Applying all these criteria leaves the sample with 23,524 observations from 52 industries representing 4,098 unique firms. To lessen the effect of outliers, all the continuous variables are winsorized at 1 percent tails.

\subsection{Selection of Suspect Observations}

Capital market motivations are considered as the most significant motivation for earnings management (Cohen and Zarowin, 2010) and particularly earnings management toward benchmarks is well-documented in the literature (e.g. Burgstahler and Dichev, 1997). As for income-decreasing earnings management, a common methodology is to test pre-managed earnings as the difference between earnings and an earnings management measure. This

\footnotetext{
${ }^{2}$ Since the sample period includes the period of financial crisis and the crisis could affect our findings, the sample is divided into crisis (i.e. 2007 through 2009) and non-crisis periods. The main results substantially hold for both periods. Including a dummy variable for crisis period does not either change the initial results.

${ }^{3}$ Moreover, given that seasonality signifies a regular predictable pattern that repeats every year, seasonality could be a serious concern if different quarters were compared, while we compare earnings made during the first three quarters of the current year to earnings made during the exact same period of the last year.
} 
approach is subject to backing-out problem which can potentially affect both suspect firms selection and estimation of earnings management. The research design of the present study addresses this issue.

Considering the time when manipulation takes place could help in its detection. The timing of earnings management is particularly useful when researchers examine the manipulation of earnings towards a target (Das et al., 2009). The timing of RAM is restricted by the fact that it must be carried out during the year when activities are still running. Given that RAM as a deviation from the optimum/normal level of activities is costly to firms, it is expected that firms postpone it until they have enough information to ensure that the required earnings cannot be otherwise met (Cohen et al., 2010). Therefore, RAM is more likely to occur towards the end of the fiscal year. Quarterly analysis of earnings, which is shown to be superior to yearly analysis (Jha, 2013), also yields results consistent with late manipulation of earnings (e.g. Kerstein and Rai, 2007; Jacob and Jorgensen, 2007; Cohen et al., 2010).

Provided that manipulation of real activities is more likely to occur near the year-end, or more technically in the fourth quarter of the fiscal year, earnings for the first three quarters could be thought of as a fair measure of pre-managed earnings. Furthermore, Last year performance has been shown by prior studies to be an important target (see DeGeorge et al., 1999). If pre-managed earnings are above earnings targets, firms may decide to push their earnings down in order to avoid reporting earnings boosts. Therefore, we select the suspects based on their performance during the first three quarters of the fiscal year expecting that firms substantially exceeding their last year performance by the end of the third quarter engage in income-decreasing manipulation.

\subsection{Variables Measurement}




\subsubsection{Dependent Variables}

Following Roychowdhury (2006), abnormal levels of cash flow from operations, production costs and discretionary expenses are employed to capture RAM. The following model is run for normal cash flow from operations:

$$
\frac{\mathrm{CFO}_{\text {it }}}{\mathrm{TA}_{\mathrm{i}, \mathrm{t}-1}}=\alpha_{0}+\alpha_{1} \frac{1}{\mathrm{TA}_{\mathrm{i}, \mathrm{t}-1}}+\alpha_{2} \frac{\mathrm{S}_{\mathrm{it}}}{\mathrm{TA}_{\mathrm{i}, \mathrm{t}-1}}+\alpha_{3} \frac{\Delta \mathrm{S}_{\mathrm{it}}}{\mathrm{TA}_{\mathrm{i}, \mathrm{t}-1}}+\varepsilon_{\mathrm{it}}
$$

where $\mathrm{CFO}_{\text {it }}$ is cash flow from operations in year $t$ for firm $i$; $\mathrm{S}_{\mathrm{it}}$ is net sales in year $\mathrm{t} ; \Delta \mathrm{S}_{\mathrm{it}}$ is net sales in year $t$ less net sales in year $t-1$ TA $_{\mathrm{it}-1}$ is total assets in year $t-1$; and $\varepsilon_{\mathrm{it}}$ is the residual.

Discretionary expenditures have long been established in the earnings management literature as an efficient and instant tool for earnings manipulation. This is because under accounting standards such spending is not permitted to be capitalised and instead immediately expensed (Xu et al., 2007). The following is used to model normal discretionary expenses, defined as the sum of R\&D, advertising, and selling, general and administrative expenses:

$$
\frac{\mathrm{DE}_{\mathrm{it}}}{\mathrm{TA}_{\mathrm{i}, \mathrm{t}-1}}=\alpha_{0}+\alpha_{1} \frac{1}{\mathrm{TA}_{\mathrm{i}, \mathrm{t}-1}}+\alpha_{2} \frac{\mathrm{S}_{\mathrm{i}, \mathrm{t}-1}}{\mathrm{TA} \mathrm{i}_{\mathrm{i}, \mathrm{t}-1}}+\varepsilon_{\mathrm{it}}
$$

where $\mathrm{DE}_{\mathrm{it}}$ is discretionary expenses in year $t$.

Manipulation of production can change operating profit. Production costs are defined as sum of cost of goods sold and inventory change. The following regression is run to estimate normal production costs:

$$
\frac{\mathrm{PC}_{\mathrm{it}}}{\mathrm{TA}_{\mathrm{i}, \mathrm{t}-1}}=\alpha_{0}+\alpha_{1} \frac{1}{\mathrm{TA}_{\mathrm{i}, \mathrm{t}-1}}+\alpha_{2} \frac{\mathrm{S}_{\mathrm{it}}}{\mathrm{TA}_{\mathrm{i}, \mathrm{t}-1}}+\alpha_{2} \frac{\Delta \mathrm{S}_{\mathrm{it}}}{\mathrm{TA}_{\mathrm{i}, \mathrm{t}-1}}+\alpha_{3} \frac{\Delta \mathrm{S}_{\mathrm{i}, \mathrm{t}-1}}{\mathrm{TA} \mathrm{i}_{\mathrm{i}, \mathrm{t}-1}}+\varepsilon_{\mathrm{it}}
$$


where $\mathrm{PC}_{\mathrm{it}}$ is production costs in year $t$ for firm $i ; \Delta \mathrm{S}_{\mathrm{it}-1}$ is net sales in year $t-1$ less net sales in year $t-2$.

The difference between actual and expected cash flow from operations using the corresponding industry-year regression is defined as abnormal cash flow from operations. Abnormal discretionary expenses and production costs are also calculated using the same logic.

Finally, AM is measured using the modified Jones model by suggested Dechow et al. $(1995)^{4}:$

$$
\frac{\mathrm{TACC}_{i t}}{\mathrm{TA}_{\mathrm{i}, \mathrm{t}-1}}=\alpha_{0}+\alpha_{1} \frac{1}{\mathrm{TA}_{\mathrm{i}, \mathrm{t}-1}}+\alpha_{2} \frac{\Delta \mathrm{S}_{\mathrm{it}}-\Delta \mathrm{REC}_{\mathrm{it}}}{\mathrm{TA}_{\mathrm{i}, \mathrm{t}-1}}+\alpha_{3} \frac{\mathrm{PPE}_{\mathrm{i}, \mathrm{t}}}{\mathrm{TA}_{\mathrm{i}, \mathrm{t}-1}}+\varepsilon_{\mathrm{it}}
$$

where TACC $_{i t}$ is the difference between earnings and CFO in year $t, \mathrm{PPE}_{\mathrm{it}}$ is gross property, plant, and equipment in year $t$ and $\triangle \mathrm{REC}_{\text {it }}$ is receivables in year $t$ less receivables in year $t-1$.

\subsubsection{Independent Variable}

The independent variable in this study is an indicator variable which denotes whether a firmyear observation is suspected of earnings management. Firms suspected of downward manipulation have experienced earnings boosts which creates the opportunity for incomedecreasing actions. Last year comparable earnings are considered as the performance target that can motivate earnings management (DeGeorge et al., 1999; Graham et al., 2005). Furthermore, Fan et al. (2010) provide evidence of earnings manipulation to meet/beat earnings of last year's same quarter. Accordingly, this study considers last year's same quarter earnings as the required minimum earnings that managers wish for, thus firms with earnings in excess of the comparable number of last year are expected to indicate downward

\footnotetext{
${ }^{4}$ Using Jones (1991) model does not substantially change the results.
} 
earnings management. Given that earnings management is likely to occur towards the end of the fiscal year, which is technically the fourth quarter, if sum of earnings of a firm for the first three quarters in the current year is significantly higher than that of last year, the firm is classified as suspected of earnings management.

\subsubsection{Empirical Model and Control Variables}

To examine the research hypotheses, the measures of earnings management are regressed on an indicator variable denoting whether an observation is suspected of earnings manipulation. The following pooled cross-sectional regression is run with a year indicator to account for any variation attributable to year effects:

$$
\begin{gathered}
\text { EMM }_{t}=\alpha+\beta_{1}(\text { SIZE })_{t-1}+\beta_{2}(\text { MTB })_{t-1}+\beta_{3}(R O A)_{t}+\beta_{4}(\text { SUSPECT })_{t}+ \\
\sum_{j} \beta_{5, j} \text { Year }_{j}+\varepsilon_{t}
\end{gathered}
$$

Where SIZE is the logarithm of the market value of equity at the beginning of the year, MTB is market to book ratio at the beginning of the year, and $R O A$ is net income before extraordinary items scaled by lagged total assets. SUSPECT is an indicator variable that is set equal to 1 if an observation belongs to the suspects and 0 otherwise. SUSPECT takes 1 if the earnings for the first three quarters of year $t$ is 50 percent more than that of the same period of last year, or:

$$
\text { SUSPECT }=1 \text { if } \frac{E_{t, Q 1}+E_{t, Q 2}+E_{t, Q 3}}{E_{t-1, Q 1}+E_{t-1, Q 2}+E_{t-1, Q 3}} \geq 1.5, \text { and } 0 \text { otherwise }
$$

$\mathrm{E}_{\mathrm{t}, \mathrm{Qj}}$ denotes earnings for the quarter $j$ of year $t$. The dependent variable, $\mathrm{EMM}_{\mathrm{t}}$, represents four measures of earnings management. The model for each dependent variable is run with a similar set of independent and control variables. 
Size, growth rate and performance are controlled for. Dechow et al. (1995) argue that earnings management models that ignore performance may be biased and that not considering performance may interfere with statistical inferences from the models. McNichols (2000) provides empirical evidence of a positive association between return on assets and earnings management. Thus, performance is controlled for using the return on assets ratio (ROA), calculated as net income before extraordinary items scaled by lagged total assets. Firms in different stages of the business cycle vary by future growth opportunities. Firms with high growth rates are expected to have higher working capital and are also more likely to engage in earnings management (McNichols, 2000). Dechow et al. (1998) indicate that growth firms need higher working capital as a response to increased sales. This implies that the variation in earnings management measures which is attributable to growth is not discretionary and should be controlled for (Collins et al., 2016). To control for growth opportunities, market to book ratio is included in the model. It should be noted that since dependent variables are expressed as deviation from industry-year means, all the above control variables are also similarly measured (Roychowdhury, 2006; Zang, 2012).

\subsection{Trade-Off between Real Activities Manipulation and Accruals Management}

In addition to testing RAM and AM individually, we also exploratorily examine the trade-off between RAM and AM for firms suspected of income-decreasing earnings management. In doing so, we follow Zang (2012) who uses Heckman (1979) two-step method. The first step involves running the following probit model using all the firm-year observations to extract the inverse Mills ratio, which will then be used in the second step 5 .

$$
\text { Suspect }_{t}=\alpha+\beta_{1}(S I Z E)_{t-1}+\beta_{2}(M T B)_{t-1}+\beta_{3}(R O A)_{t}+\beta_{4}(N O S)_{t}+\sum_{j} \beta_{5, j} \text { Year }_{j}+\varepsilon_{t}
$$

\footnotetext{
5 Since we examine income-decreasing earnings management, variables related to income increasing motivations in the original probit model suggested by Zang (2012) are excluded.
} 
Since earnings targets tend to be expressed per share, $\mathrm{NOS}_{t}$ which is the log of number of outstanding shares, is included in the model. All other variables are as previously defined.

The second step involves testing the relationship between the level of earnings management and its costs which is carried out separately for RAM and AM using the following regressions:

$$
\begin{gathered}
\mathrm{RAM}_{t}=\beta_{0}+\sum_{k} \beta_{1, k} R A M_{-} \operatorname{COST}_{k, t}+\sum_{l} \beta_{2, l} \text { AM }_{-} \operatorname{COST}_{l, t}+\sum_{m} \beta_{3, m} \operatorname{CONTROL}_{m, t}+u_{t} \\
\mathrm{AM}_{t}=\beta_{0}+\sum_{k} \gamma_{1, k} \text { AM_COST }_{k, t}+\sum_{l} \gamma_{2, l} \text { RAM }_{-} \operatorname{COST}_{l, t}+\gamma_{3, n} \text { EXP_RAM }_{t}+\gamma_{4, p} \text { UNEXP_RAM }_{t}+ \\
\sum_{m} \gamma_{5, m} \text { CONTROL }_{m, t}+v_{t}
\end{gathered}
$$

$\mathrm{RAM}_{t}$ is the total amount of activities manipulation in year $t$ computed as the sum of abnormal discretionary expenses multiplied by minus one and abnormal production costs $^{6}$, and $\mathrm{AM}_{t}$ is accruals management captured from Equation (4). RAM_COST denotes the costs of involvement in activities manipulation which includes market share, financial health, institutional ownership and marginal tax rate. Market share of a firm at the beginning of the period $\left(\mathrm{MS}_{t-1}\right)$ is measured as the ratio of a firm's sales revenue to the total sales of its corresponding industry using two-digit SIC codes. The higher the market share, the lower the cost of RAM. Financial health is measured by Altman's Z-score (Altman, 1968) at the beginning of the period $\left(\mathrm{Z}_{-} \mathrm{SCORE}_{t-1}\right)$. Healthier firms are expected to have lower RAM costs. Institutional ownership is captured by the percentage of institutional ownership at the beginning of the period (IOWN $\mathrm{N}_{t-1}$ ) and is expected to have a direct relation to the cost of RAM. The last cost is marginal tax rate $\left(\mathrm{MTR}_{t}\right)$ proxied by the effective tax rate in year $t$. AM_COST denotes the costs of accruals management including presence of Big Four Auditors $\left(\right.$ BIG_FOUR $_{t}$ ) and two measures of accounting system flexibility i.e. net operating assets at the beginning of the period $\left(\mathrm{NOA}_{t-1}\right)$ and the length of operating cycle $\left(\mathrm{OC}_{t-1}\right)$. Big

\footnotetext{
${ }^{6}$ The results remain consistent when individual activities manipulation measures are used instead of $\mathrm{RAM}_{t}$.
} 
Auditors are expected to deliver higher quality audits making AM costly for their clients. On the other hand, lower flexibility of accounting system increases the cost of involvement in AM.

In both equations, size, growth and profitability are controlled for using variables that are previously defined i.e. $\operatorname{SIZE}_{t}, \mathrm{MTB}_{t}$, and $\mathrm{ROA}_{t}$, respectively. The inverse Mills ratio $\left(\mathrm{IMR}_{t}\right)$ extracted from the RAM model (Equation 7) is included in the AM model (Equation 8) to account for any potential selection bias. Since AM depends on the expected and unexpected levels of activities manipulation, EXP_RAM ${ }_{t}$ and UNEXP_RAM $t$ are also included in the AM model. EXP_RAM ${ }_{t}$ is the predicted level of activities manipulation and UNEXP_RAM ${ }_{t}$ is the residual, both extracted from Equation (7).

\section{Results}

\subsection{Descriptive Statistics}

Table 1 reports descriptive analysis of the whole sample as well as a comparison between the suspects and the rest of the sample. The first striking point is that the suspects $(n=9,330)$ constitute almost 40 percent of the entire sample, which indicates that the opportunity for income-decreasing earnings management is abundant. The suspects on average have less net income at \$272 million compared to \$385 million for the rest of the sample. In terms of market value of equity, the suspects are substantially smaller than others as they have a mean market value of equity of $\$ 1962$ million while that of non-suspects is $\$ 3555$. Turning to growth, the average market to book value for all firm-years is 3.25 while the suspects have a greater market to book value (mean $M T B=3.90$ ) compared with the rest of the sample (mean $M T B=2.82$ ). Furthermore, means and medians of almost all the variables are significantly different for suspects and non-suspects which suggests that the indicator variable splits the sample into two distinct groups. The suspects, in scaled terms, have a lower mean of cash 
flow from operations, lower production costs and greater discretionary expenses compared to the rest of the sample, which are all consistent with the predictions in the research hypotheses as they suggest income-decreasing actions by the suspects. However, the suspects have higher absolute and scaled accruals than the rest of the sample, which is in line with the second hypothesis.

\section{[Insert Table 1 here]}

Table 2 reports the summary statistics for the variables used in Equation (5) separately for the suspects $(n=9330)$ and the rest of the sample $(n=14194)$, as well as the correlations. Suspect firm-years show a negative mean for abnormal cash flow from operations (ABNCFO $=-0.0143)$, a positive mean for abnormal discretionary expenses $(\mathrm{ABNDE}=0.0227)$ and $\mathrm{a}$ negative mean for abnormal production costs $(\mathrm{ABNPC}=-0.0013)$ which are all consistent with the research hypotheses as they all suggest downward manipulation. The mean of all the measures of earnings management for the entire sample is very close to zero. This is as anticipated since with a large sample it is expected that on average abnormal figures approach zero. The sign of the mean of earnings management measures for the suspects are as predicted in the research hypotheses, and the sign for non-suspects are exactly the opposite. In addition to providing initial evidence for rejecting null hypotheses, this provides corroborating evidence that the variable SUSPECT is an effective partitioning variable as it divides the sample into two groups that are different in terms of earnings management.

Pearson (lower triangle) and Spearman (upper triangle) correlations for the variables in Equation (5) are presented in Panel B. The correlation between abnormal cash flow from operations and abnormal accruals is consistent with Roychowdhury (2006), Cohen et al. (2008) and Cohen and Zarowin (2010). All measures of real earnings management are 
negatively correlated to each other, which is also consistent with the results reported by Roychowdhury (2006), Cohen et al. (2008) and Chi et al. (2011).

[Insert Table 2 here]

\subsection{Main Results}

As predicted in the first hypothesis, Table 3 shows that the coefficient on SUSPECT for CFO model is negative (-0.0145) and significant at $1 \%$ which suggests income-decreasing manipulation. The coefficient on SUSPECT for the production costs model is negative (0.0069 ) and significant at $5 \%$ which also suggests downward manipulation. This is consistent with prior studies that indicate firms manipulate their production to report a favourable earnings figure (e.g. Roychowdhury, 2006; Zang, 2012; and Cook et al., 2012). As previously mentioned, manipulation of discretionary expenses is probably the most convenient way to manage earnings. This is well reflected in the positive sign, magnitude and significance of the coefficient on SUSPECT in the discretionary expenses model, since the coefficient is positive, i.e. income-decreasing, and is the largest amongst all the models. These results are consistent with those of Comprix et al. (2006) who report that firms increase their selling, general and administrative expenses to reduce their earnings. It is worth noting that out of 9,330 observations that showed at least 50 percent increase in their earnings during the first three quarters compared to their last year performance, only $34.3 \%$ have continued this improvement in the fourth quarter and majority of the suspects $(65.7 \%$ or 6,133 observations) show lower performance by the end of the year which corroborates the incomedecreasing real activities manipulation evidence revealed by the regression results The second hypothesis is devoted to the behaviour of the suspects in terms of AM. The suspects have abnormal accruals that are $0.8 \%$ of the total assets larger than those of the rest of the sample. This indicates that the suspects do not use AM for downward earnings management as predicted in the hypothesis. This finding is consistent with the prominent 
shift from AM to RAM (Cohen et al., 2008) as it suggests that firms with incentives for income-decreasing manipulation tend to use RAM rather than AM. The abnormally higher accruals of the suspects could be a statistical artefact of the direct relationship between earnings and accruals since firms suspected of income-increasing manipulation are those with substantial earnings growth. In other words, in the absence of manipulation, growth in earnings results in higher total accruals which in turn leads to higher discretionary accruals.

[Insert Table 3 here]

\subsection{Trade-off Between Accruals Management and Real Activities Manipulation}

\subsubsection{First-Step Heckman Results}

First-step Heckman results are presented in Table 4. The first step involves running the probit model (Equation 6) for the whole sample $(n=22,822)$ to obtain inverse Mills ratio in order to tackle any potential selection bias. The significantly negative coefficient on $\mathrm{SIZE}_{t}$ and significantly positive coefficient on $\mathrm{MTB}_{t}$ indicate that small and growth firms are more likely to engage in downward earnings management, which is consistent with our initial descriptive analysis reported in Table 1 . The negative coefficient on $\mathrm{NI}_{t}$ suggests that the suspects sample contains loss firms. ${ }^{7}$

\section{[Insert Table 4 here]}

\subsubsection{Second-Step Heckman Results}

Table 5 reports summary statistics for the variables used in the second step as well as correlation coefficients. The results suggest that the suspects are small with a mean market share $\left(\mathrm{MS}_{t-1}\right)$ of $1 \%$ and financially healthy with a mean $\mathrm{Z}_{-} \mathrm{SCORE}_{t}$ of above 4 . In line with the probit model results, the mean of return on assets $\left(\mathrm{ROA}_{t}\right)$ is negative. The mean of BIG-

\footnotetext{
${ }^{7}$ This finding is more closely examined in Section 4.4.2 Profit Firms versus Loss Firms.
} 
_FOUR ${ }_{t}$ is $63 \%$ which indicates that most of the suspects are audited by Big 4 . Panel B shows Pearson (lower triangle) and Spearman (upper triangle) correlations among the variables used in the second step. RAM and AM are not highly correlated which implies that the suspects use these methods as substitutes, which is consistent with prior studies (Cohen and Zarowin 2010; Zang, 2012; Braam et al., 2015). Generally, RAM of the suspects is not related to the earnings management costs while AM is negatively related to the costs. This finding suggests

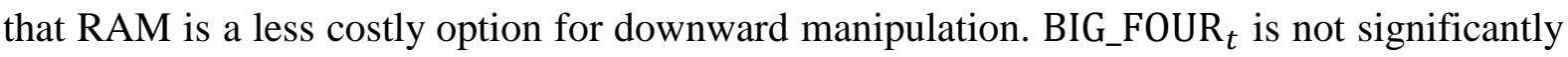
related to RAM while it is negatively correlated with AM, which indicates the role of quality audits in mitigating AM.

\section{[Insert Table 5 here]}

The second step only contains firms suspected of downward manipulation $(n=2,973)$. The coefficients on the costs of RAM are generally weak and insignificant which suggests that, in a setting where downward earnings management is expected, the level of RAM is not related to the earnings management costs. In other words, RAM does not appear to be a costly tool for downward manipulation. Turning to the AM model, the coefficient on BIG_FOUR $t$ is significantly negative which suggests that Big auditors are associated with lower levels of AM. The positive coefficient on $\mathrm{NOA}_{t-1}$ shows that the higher the flexibility in the accounting system, the larger AM. The only economically significant cost of RAM is $\mathrm{MS}_{t-1}$ which implies that firms with higher market shares involve in higher AM, while the rest of RAM costs are only statistically (not economically) significant. In both RAM and AM models, low adjusted $R^{2}$ suggests that the costs of manipulation may not convincingly explain RAM and AM in a setting where downward manipulation is expected. Particularly, in the RAM model, most of the costs of earnings management are statistically/economically insignificant. However, the AM model indicates a much higher $R^{2}$ compared with the RAM 
model, and the coefficients are much more significant both statistically and economically. These findings by and large suggest that when downward earnings management is expected, RAM is less costly than AM. This is consistent with our initial results (see Table 3) since the suspects do not show income-decreasing AM while they are involved in downward RAM.

[Insert Table 6 here]

\subsection{Robustness Tests}

\subsubsection{Alternative Performance Thresholds}

It has so far been assumed that the performance threshold for income-decreasing earnings management is 50 percent. In this section this assumption is relaxed to find out whether and how the results are sensitive to the change in the performance threshold. To this end, alternative performance thresholds are introduced ranging from 20 percent to 250 percent. To examine the impact of performance threshold choice on the results, Equation (5) is re-run using alternative definitions of SUSPECT. Table 7 provides the coefficients on SUSPECT for the four earnings management models. Consistent with the results of abnormal cash flow from operations, income-decreasing earnings management is observed for the entire range and SUSPECT remains negative and very significant. This is also the case with abnormal production costs, albeit of less magnitude and significance. Abnormal discretionary expenses remain very significant over the range and shows a steady increase with the amount of extra earnings. The results for abnormal accruals are also mainly consistent with the initial performance threshold. Overall, using alternative performance thresholds to select the suspect seems not to substantially affect the initial results where $50 \%$ was used.

[Insert Table 7 here]

\subsubsection{Profit Firms versus Loss Firms}


The main criterion for determining firms suspected of income-decreasing earnings management is the presence of earnings boosts by the end of the third quarter. Hence, the suspects can include both profit and loss firms. While the empirical results are consistent with the expectation that the suspects manage their earnings downwards, this behaviour might vary depending on whether a suspect firm reports a profit or loss. Firms reporting a loss are generally considered as less involved in earnings management than those reporting a profit. Dechow et al. (2003) argue that small loss firms are expected to be similar to the average in terms of AM as upward earnings management to switch from a larger loss to a small loss is not justifiable. However, in light of the reported disappearance of zero-earnings discontinuity (Gilliam et al., 2015), Makarem et al. (2018) report that small loss firms are involved in upward manipulation of accruals and real activities. Accordingly, it is interesting to compare profit and loss firms in a setting where downward earnings management is expected.

Of the entire suspects $(n=9,330), 36 \%$ are loss making $(n=3327)$. A loss-making firm can have incentives to manage its earnings downwards if it believes that the market expects a loss to continue and a lower improvement is sufficient to indicate good performance. Thus, the suspects are divided into loss-making and profitable firms to investigate any difference between them in terms of earnings management. Table 8 reports the results separately for loss making and profitable suspect firms. In general, while profitable suspect firms indicate income-decreasing RAM, loss making firms are engaged in income-increasing manipulation. Loss firms also show income-increasing abnormal accruals. The results suggest that loss firms push their earnings up in order to report a lower loss. However, a closer investigation of earnings management is required to analyse such a difference which is an interesting avenue for future research.

[Insert Table 8 here] 


\section{Concluding Remarks}

This study provides evidence that firms that substantially outperformed their last year earnings during the first three quarters push their earnings down to avoid reporting earnings boosts. The results generally suggest that firms suspected of manipulation are involved in income-decreasing RAM as they exhibit lower cash flow from operation and production costs and greater discretionary expenses than the rest of observations. The results for AM indicate that the suspects have greater abnormal accruals. We argue that the abnormally higher accruals of the suspects could be a statistical artefact of the direct relationship between earnings and accruals. We also provide evidence that RAM is less costly to downward manipulators than AM. These findings are collectively consistent with the prominent shift from AM to RAM. We also report that, despite the general notion that loss firms are less involved in earnings management, loss firms indicate income-increasing earnings management. The results suggest that, when income-decreasing earnings management is expected, loss and profit firms should be separately examined since their behaviour could be different.

While users tend to be more worried about income-increasing manipulation, our findings highlight the use of income-decreasing manipulation of activities which could be valuedestroying. Furthermore, this study highlights the importance of interim financial reports. The users should be more vigilant of firms exceeding their last year interim results as they could be involved in downward manipulation of real activities.

This study solely uses one single earnings benchmark i.e. last year earnings. Although it seems reasonable to assume that firms that outperformed their last year earnings by a large margin have also exceeded other earnings benchmarks, further research may individually or collectively examine other benchmarks including analysts' forecasts. A closer investigation 
of the earnings management behaviour of profit and loss making firms triggered by other income-decreasing incentives could also be worthwhile. 


\section{References}

Altman, E. (1968), "Financial ratios, discriminate analysis and the prediction of corporate bankruptcy". Journal of Finance, Vol. 23 No. 4, 589-609.

Baker, T., Collins, D., \& Reitenga, A. (2003), "Stock-option compensation and earnings management incentives”, Journal of Accounting, Auditing and Finance, Vol. 18, pp. $557-582$.

Barth, M., Elliot, J., and Finn, M. (1999). "Market rewards associated with patterns of increasing earnings". Journal of Accounting Research, Vol. 37, pp. 387-413.

Barua, A., J. Legoria, and Moffitt, J. S. (2006), “Accruals management to achieve earnings benchmarks: A comparison of pre-managed profit and loss firms", Journal of Business, Finance \& Accounting, Vol. 33, pp. 653-670.

Braam, G., Nandy,M.,Weitzel, U., and Lodh, S. (2015), “Accrual-based and real earnings management and political connections”, International Journal of Accounting, Vol. 50, pp. 111-141.

Brown, L., \& Pinello, A. (2007) 'To what extent does the financial reporting process curb earnings surprise games?', Journal of Accounting Research, Vol. 45, pp. 947-981.

Burgstahler, D. and Dichev, I. (1997), "Earnings management to avoid earnings decreases and losses”, Journal of Accounting and Economics, Vol. 24, pp. 99-126.

Burgstahler, D. C., and Eames, M. (2006). "Management of earnings and analysts' forecasts to achieve zero and small positive earnings surprises". Journal of Business Finance \& Accounting, Vol. 33, pp. 633-652. 
Chan, L. H., Chen, K. C. W., Chen, T. Y., and Yu, Y. (2015), "Substitution between real and accruals-based earnings management after voluntary adoption of compensation clawback provisions”, Accounting Review, Vol. 90 No. 1, pp. 147-174.

Chi, W., Ling Lei, L., \& Mikhail, P. (2011), "Is enhanced audit quality associated with greater real earnings management?”, Accounting Horizons, Vol. 25, 315-335.

Cohen, D. A., \& Zarowin, P. (2010), “Accrual-based and real earnings management activities around seasoned equity offerings", Journal of Accounting and Economics, Vol. 50, 2-19.

Cohen, D., Dey, A., \& Lys, T. (2008), "Real and accrual-based earnings management in the pre- and post-Sarbanes-Oxley periods", The Accounting Review, Vol. 83, 757-787.

Cohen, D., R. Mashruwala, \& T. Zach. (2010) 'The use of advertising activities to meet earnings benchmarks: Evidence from monthly data', Review of Accounting Studies, Vol. 15, pp. 808-832.

Coles, J., Hertzel, M., \& Kalpathy, S. (2006), “Earnings management around employee stock option reissues", Journal of Accounting and Economics, Vol. 41, 173-200.

Collins, D. W., Pungaliya, R. S., \& Vijh, A. M. (2016), “The effects of firm growth and model specification choices on tests of earnings management in quarterly settings", The Accounting Review, Vol. 92, 69-100.

Comprix, J., Mills, L., and Schmidt, A. (2006), Earnings management to meet or beat analyst earnings forecasts through changes in interim expenses, available at: https://www8.gsb.columbia.edu/faculty-research/sites/facultyresearch/files/accounting/SCHMIDT.pdf (accessed 20 September 2018). 
Cook, K. A., Huston, G. R., and Kinney, M. (2012), “Managing earnings by manipulating inventory: the effects of cost structure and valuation method", working paper available at: https://papers.ssrn.com/sol3/papers.cfm?abstract_id=997437 (accessed 20 September 2018)

Das, S., Shroff, P. K., \& Zhang, H. (2009) 'Quarterly earnings patterns and earnings management', Contemporary Accounting Research, Vol. 26, pp. 797-831.

Daske, H., Gebhardt, G. and McLeay, S. (2006). "The distribution of earnings relative to targets in the European Union", Accounting and Business Research, Vol. 36, No. 3, pp. 137-167.

DeAngelo, H., DeAngelo, L., and Skinner, D. (1996). "Reversal of fortune: Dividend signaling and the disappearance of sustained earnings growth”. Journal of Financial Economics, Vol. 40, pp. 341-371.

Dechow, P.M., Richardson, S.A., \& Tuna, I. (2003) 'Why are earnings kinky?' Review of Accounting Studies, Vol. 8, pp. 355-384.

Dechow, P., Kothari, S., \& Watts, R. (1998), “The relation between earnings and cash flows”, Journal of Accounting and Economics, Vol. 25, 133-168.

Dechow, P., Sloan, R., \& Sweeney, A. (1995) 'Detecting earnings management', The Accounting Review, Vol. 70, pp. 193-225.

DeFond, M., \& Park, C. (1997), "Smoothing income in anticipation of future earnings", Journal of Accounting and Economics, Vol. 23, 115-139.

DeGeorge, F., Patel, J., \& Zeckhauser, R. (1999) 'Earnings management to exceed thresholds', Journal of Business Finance \& Accounting, Vol. 72, pp. 1-33. 
Dyreng, S. D., W. J. Mayew, and K. Schipper. (2017), "Evidence of Manager Intervention to Avoid Working Capital Deficits”, Contemporary Accounting Research, Vol. 34, pp. 697-725.

Fan, Y., Barua, A., Cready, W., \& Thomas, W. (2010) 'Managing earnings using classification shifting: evidence from quarterly special items', The Accounting Review, Vol. 85, pp. 1303-1323.

Francis, B., Hasan, I., \& Li, L. (2016) 'Evidence for the existence of downward real-activity earnings management', Journal of Accounting, Auditing \& Finance, Vol. 31, pp. 212-248.

Fudenberg, D., \& Tirole, J. (1995), “A theory of income and dividend smoothing based on incumbency rents", Journal of Political Economy, Vol. 103, 75-93.

Gilliam, T. A., Heflin, F., and Paterson, J.S. (2015), "Evidence that the zero-earnings discontinuity has disappeared", Journal of Accounting and Economics, Vol. 60, pp. 117-132.

Gong, G., Louis, H., \& Sun, A. (2008) 'Earnings management, lawsuits, and stock-for-stock acquirers' market performance', Journal of Accounting and Economics, Vol. 46, pp. $62-77$.

Graham, J. R., Harvey, C.R, \& Rajgopal, S. (2005) 'The economics implications of corporate financial reporting', Journal of Accounting and Economics, Vol. 40, pp. 3-73.

Gunny, K. (2010) 'The relation between earnings management using real activities manipulation and future performance: Evidence from meeting earnings benchmarks', Contemporary Accounting Research, Vol. 27, pp. 1-34. 
Healy, P. M. (1985), “The effect of Bonus schemes on accounting decisions”, Journal of Accounting and Economics, Vol. 7, 85-107.

Healy, P. M. and Whalen, J. M. (1999), “A review of the earnings management literature and its implications for standard setting”, Accounting Horizons, Vol. 13, pp. 365-83.

Heckman, J. J. (1979), “Sample selection bias as a specification error”, Econometrica Vol. 47 No. 1, pp. 153-161.

Jackson, S., \& Wilcox, W. (2000), "Do managers grant sales price reductions to avoid losses and declines in earnings and sales?' Quarterly Journal of Business and Economics, Vol. 39, pp. 3-20.

Jacob, J., \& Jorgensen, B. (2007), "Earnings management and accounting income aggregation', Journal of Accounting and Economics, Vol. 43, pp. 369-390.

Jha, A. (2013) 'Earnings management around debt-covenant violations - an empirical investigation using a large sample of quarterly data', Journal of Accounting, Auditing \& Finance, Vol. 28, pp. 369-396.

Jiang, H., Hu, Y., Zhang, H., \& Zhou, D. (2018), "Benefits of Downward Earnings Management and Political Connection: Evidence from Government Subsidy and Market Pricing”, The International Journal of Accounting, Vol. 53, No. 4, pp. 255273.Jones, J. (1991) 'Earnings management during import relief investigations', Journal of Accounting Research, Vol. 29, pp. 193-228.

Kahneman, D., Tversky, A. (1979), "Prospect theory: an analysis of decision under risk", Econometrica, Vol. 47, pp. 263-291. 
Kang, S., \& Sivaramakrishnan, K. (1995), 'Issues in testing earnings management and an instrumental variable approach", Journal of Accounting Research, Vol. 33, pp. 353367.

Kerstein, J., \& Rai, A. (2007), "Intra-year shifts in the earnings distribution and their implications for earnings management", Journal of Accounting and Economics, Vol. 44, pp. 399-419.

Koh, K., Matsumoto, D. and Rajgopal, S. (2008), "Meeting or beating analyst expectations in the post-scandals world: changes in stock market rewards and managerial actions", Contemporary Accounting Research, Vol. 25 No. 4, pp. 1067-1098.

Lim, S., \& Lustgarten, S. (2002) 'Testing for income smoothing using the backing out method: a review of specification issues', Review of Quantitative Finance and Accounting, Vol. 19, pp. 273-290.

Louis, H. (2004). "Earnings management and the market performance of acquiring firms". Journal of Financial Economics, Vol. 74, pp. 121-148.

Makarem, N., Hussainey, K., and Zalata, A. (2018), "Earnings Management in the Aftermath of the Zero-Earnings Discontinuity Disappearance", Journal of Applied Accounting Research, Vol. 19 No. 3, pp. 401-422.

Marquardt, C. A., Wiedman, C. I. (2004). "How are earnings managed? An examination of specific accruals”. Contemporary Accounting Research, Vol. 21, pp. 461-491.

Matsumoto, D. A. (2002), “Management's incentives to avoid negative earnings surprises”, The Accounting Review, Vol. 77, 483-514. 
McAnally, M., Srivastava, A., Weaver, C. (2008), "Executive stock options, missed earnings targets, and earnings management", Accounting Review, Vol. 83, 185-216.

McDonnell, M.H., Pierce, S., Thornock, J.R. (2019), "Looking your Worst: Downward Earnings Management after Activist Challenges", working paper available at: https://papers.ssrn.com/sol3/papers.cfm?abstract_id=3349387 (accessed 27 August 2019)

McNichols, M. F. (2000), "Research design issues in earnings management studies", Journal of Accounting and Public Policy, Vol. 19, 313-345.

Monem, R. (2003), "Earnings management in response to the introduction of the Australian gold tax”, Contemporary Accounting Research, Vol. 20, pp. 747-774.

Moore, M. (1973), "Management changes and discretionary accounting decisions", Journal of Accounting Research, Vol. 10, 100-107.

Mora, A., Sabater, A. (2008), "Evidence of income-decreasing earnings management before labor negotiations within firms”, Investigaciones Economicas, Vol. 32, pp. 201-230.

Orozco, L, and Rubio, S. (2018), "Regulatory Capital Management to Exceed Thresholds", working paper, Available at: http://dx.doi.org/10.2139/ssrn.3234652

Payne, J. and Robb, S. (2000). "Earnings Management: The Effect of Ex Ante Earnings Expectations". Journal of Accounting, Auditing and Finance, Vol. 15 No. 4, pp. $371-92$.

Peasnell, K. V., Pope, P.F., \& Young, S. (2005) 'Board monitoring and earnings management: do outside directors influence abnormal accruals?', Journal of Business Finance \& Accounting, Vol. 32, pp. 1311-1346. 
Roychowdhury, S. (2006) 'Earning management through real activities manipulation', Journal of Accounting and economics, Vol. 42, pp. 335-370.

Sawicki, J., Shrestha, K. (2008), “Insider Trading and Earnings Management”, Journal of Business Finance \& Accounting, Vol. 35 No. 3-4, pp. 331-346.

Shon, J., \& Yan, M. (2015) 'R\&D cuts and subsequent reversals: meeting or beating quarterly analyst forecasts', European Accounting Review, Vol. 24, pp. 147-166.

Teoh, S. H., Welch, I., and Wong, T.J. (1998a). "Earnings Management and the Long-Run Market Performance of Initial Public Offerings.” Journal of Finance, Vol. 53 No. 6, pp. 1935-1974.

Teoh, S. H., Welch, I., and Wong, T.J. (1998b). "Earnings Management and the Underperformance of Seasoned Equity Offerings.” Journal of Financial Economics, Vol. 50 No. 1, pp. 63-99.

Tucker, J., and Zarowin, P. (2006), "Does income smoothing improve earnings informativeness?", Accounting Review, Vol. 81, pp. 251-270.

Walker, M. (2013). "How far can we trust earnings numbers? What research tells us about earnings management.", Accounting and Business Research, Vol. 43 No. 4, pp. 445481.

Watts, P. L., \& Zimmerman, J. L. (1986), “Positive accounting theory”, New Jersey: Prentice Hall.

Xu, R., G. K. Taylor, \& Dugan, M. T. (2007), "Review of real earnings management literature", Journal of Accounting Literature, Vol. 46, 195-228. 
Zang, A. Y. (2012) 'Evidence on the trade-off between real activities manipulation and accrual-based earnings management', The Accounting Review, Vol. 87, pp. 675-703. 


\section{Table 1. Descriptive Statistics}

\begin{tabular}{|c|c|c|c|c|c|c|c|c|}
\hline \multirow[b]{2}{*}{$\underline{\text { Variable }}$} & \multicolumn{2}{|c|}{$\begin{array}{c}\text { Whole Sample } \\
\quad(\mathrm{n}=23,524)\end{array}$} & \multicolumn{2}{|c|}{$\begin{array}{l}\text { Suspects } \\
(\mathrm{n}=9,330)\end{array}$} & \multicolumn{2}{|c|}{$\begin{array}{l}\text { Rest of Sample } \\
(\mathrm{n}=14,194)\end{array}$} & \multicolumn{2}{|c|}{ Difference in } \\
\hline & $\underline{\text { Mean }}$ & $\underline{\text { Median }}$ & $\underline{\text { Mean }}$ & $\underline{\text { Median }}$ & $\underline{\text { Mean }}$ & $\underline{\text { Median }}$ & $\underline{\text { Means }}$ & $\underline{\text { Medians }}$ \\
\hline$S$ (\$ million) & 7277.39 & 312.43 & 5288.88 & 158.80 & 8584.48 & 466.40 & $3295.59 * * *$ & $-307.6 * * *$ \\
\hline TA (\$ million) & 7553.19 & 419.03 & 5825.15 & 228.01 & 8688.93 & 626.39 & $2863.78 * * *$ & $-398.38 * * *$ \\
\hline$M V \$$ (million) & 2923.45 & 365.09 & 1961.81 & 215.52 & 3555.56 & 502.35 & $1593.74 * * *$ & $-286.83 * * *$ \\
\hline MTB & 3.25 & 1.74 & 3.90 & 1.79 & 2.82 & 1.7 & $-1.0816 * * *$ & $0.09 * * *$ \\
\hline CFO (\$ million) & 635.02 & 30.70 & 476.13 & 11.79 & 739.54 & 50.38 & $263.41 * * *$ & $-38.59 * * *$ \\
\hline$P C$ (\$ million) & 4847.36 & 180.64 & 3578.52 & 87.60 & 5683.15 & 271.63 & $2104.63 * * *$ & $-184.03 * * *$ \\
\hline$D E$ (\$ million) & 1421.62 & 65.52 & 1012.57 & 41.65 & 1693.75 & 90.68 & $681.18 * * *$ & $49.03 * * *$ \\
\hline$T A C C$ (\$ million) & -294.33 & -15.31 & -203.61 & -6.69 & -354.01 & -25.63 & $-150.40 * * *$ & $18.94 * * *$ \\
\hline NI (\$ million) & 340.55 & 10.72 & 272.51 & 4.2 & 385.27 & 18.2 & $112.75^{* * *}$ & $14.00 * * *$ \\
\hline$S / T A$ & 1.13 & 0.91 & 1.11 & 0.86 & 1.13 & 0.93 & $0.0208 * * *$ & $-0.07 * * *$ \\
\hline$C F O / T A$ & 0.07 & 0.08 & 0.05 & 0.07 & 0.08 & 0.09 & $0.0384 * * *$ & $-0.02 * * *$ \\
\hline$P C / T A$ & 0.80 & 0.57 & 0.78 & 0.51 & 0.81 & 0.59 & $0.0290 * *$ & $-0.08 * * *$ \\
\hline$D E / T A$ & 0.32 & 0.24 & 0.36 & 0.27 & 0.30 & 0.23 & $-0.0581 * * *$ & $0.04 * * *$ \\
\hline$T A C C / T A$ & -0.07 & -0.05 & -0.06 & -0.05 & -0.07 & -0.05 & -0.0090 & $0.00 * * *$ \\
\hline
\end{tabular}

This table presents summary statistics for the whole sample as well as separately for suspect firms and the rest of sample. To lessen the effect of outliers, all the continuous variables are winsorized at 1 percent tails. *, **, *** indicate that the difference is significant at $10 \%, 5 \%$, and $1 \%$, respectively.

Variable definitions:

$S=$ net sales or revenue

$\boldsymbol{T A}=$ total assets

$\boldsymbol{M} \boldsymbol{V}=$ market value of equity

MTB = market to book ratio in current year

$\boldsymbol{C F O}=$ cash flow from operations

$\boldsymbol{P C}=$ production costs for year $t$ as the sum of inventory change and cost of goods sold

$\boldsymbol{D E}=$ discretionary expenses as sum of selling, general, and administrative expenses, advertising expenses, and research and development expenses

$\boldsymbol{T A C C}=$ total accruals as net income before extraordinary items minus cash flow from operations

$\boldsymbol{N I}=$ net income before extraordinary items 
Table 2. Descriptive Statistics for Metrics of Earnings Management and Control Variables

\section{Panel A*: Summary Statistics}

\begin{tabular}{|c|c|c|c|c|c|c|c|c|c|}
\hline \multirow{2}{*}{$\underline{\text { Variable }}$} & \multicolumn{3}{|c|}{ Mean } & \multicolumn{3}{|c|}{ Median } & \multicolumn{3}{|c|}{ Standard Deviation } \\
\hline & $\underline{\text { Suspect }}$ & $\underline{\text { Rest }}$ & Whole & $\underline{\text { Suspect }}$ & $\underline{\text { Rest }}$ & Whole & $\underline{\text { Suspect }}$ & $\underline{\text { Rest }}$ & Whole \\
\hline$A B N C F O$ & -0.0143 & 0.0094 & 0.0000 & -0.0025 & 0.0144 & 0.0086 & 0.1876 & 0.1453 & 0.1638 \\
\hline$A B N P C$ & -0.0013 & 0.0008 & 0.0000 & 0.0082 & 0.0064 & 0.0073 & 0.2361 & 0.2201 & 0.2266 \\
\hline$A B N D E$ & 0.0227 & -0.0151 & 0.0000 & -0.0129 & -0.0294 & -0.0230 & 0.2522 & 0.2253 & 0.2372 \\
\hline$A B N A C C J$ & 0.0062 & -0.0041 & 0.0000 & 0.0076 & 0.0052 & 0.0059 & 0.1721 & 0.1353 & 0.1511 \\
\hline SIZE & 8.2209 & 8.6663 & 8.4896 & 8.2470 & 8.7363 & 8.5515 & 0.9784 & 0.9902 & 1.0093 \\
\hline MTB & 3.5423 & 3.0286 & 3.2323 & 1.6860 & 1.9434 & 1.8438 & 17.2211 & 8.0564 & 12.5236 \\
\hline ROA & -0.0172 & 0.0130 & 0.0010 & 0.0324 & 0.0455 & 0.0413 & 0.2788 & 0.2515 & 0.2631 \\
\hline
\end{tabular}

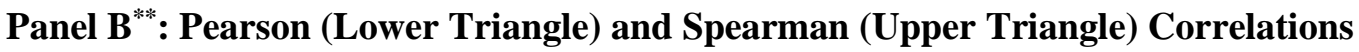

\begin{tabular}{|c|c|c|c|c|c|c|c|}
\hline Variable & $\underline{A B N C F O}$ & $\underline{A B N P C}$ & $\underline{A B N D E}$ & $\underline{A B N A C C J}$ & $\underline{R O A}$ & $\underline{S I Z E}$ & $\underline{M T B}$ \\
\hline$A B \overline{N C F O}$ & & -0.39 & -0.16 & -0.23 & 0.50 & 0.21 & 0.12 \\
\hline$A B N P C$ & -0.32 & & -0.57 & 0.09 & -0.25 & -0.09 & -0.19 \\
\hline$A B N D E$ & -0.27 & -0.57 & & -0.14 & -0.12 & -0.06 & 0.15 \\
\hline ABNACCJ & -0.09 & 0.05 & -0.21 & & 0.28 & -0.03 & -0.03 \\
\hline$R O A$ & 0.58 & -0.17 & -0.29 & 0.37 & & 0.32 & 0.13 \\
\hline SIZE & 0.15 & -0.06 & -0.06 & -0.01 & 0.23 & & 0.31 \\
\hline MTB & 0.01 & -0.04 & 0.08 & -0.05 & -0.014 & 0.04 & \\
\hline
\end{tabular}

* Panel A reports the mean, median, and standard deviation of the variables used in Equation (5). The summary statistics are separately provided by suspect firm-years and other firm-years, as well as the entire sample.

Variable definitions:

$\boldsymbol{A B N C F O}=$ abnormal cash flow from operations which is measured by the estimated residual from the following regression:

$$
\frac{C F O_{i t}}{T A_{i, t-1}}=\alpha_{0}+\alpha_{1} \frac{1}{T A_{i, t-1}}+\alpha_{2} \frac{S_{i t}}{T A_{i, t-1}}+\alpha_{3} \frac{\triangle S_{i t}}{T A_{i, t-1}}+\varepsilon_{i t}
$$

$\boldsymbol{A B N P C}=$ abnormal production costs which is measured by the estimated residual from the following regression:

$$
\frac{P C_{i t}}{T A_{i, t-1}}=\alpha_{0}+\alpha_{1} \frac{1}{T A_{i, t-1}}+\alpha_{2} \frac{S_{i t}}{T A_{i, t-1}}+\alpha_{2} \frac{\triangle S_{i t}}{T A_{i, t-1}}+\alpha_{3} \frac{\triangle S_{i, t-1}}{T A_{i, t-1}}+\boldsymbol{\varepsilon}_{i t}
$$

$\boldsymbol{A B N D E}=$ abnormal discretionary expenses which is measured by the estimated residual from the following regression:

$$
\frac{D E_{i t}}{T A_{i, t-1}}=\alpha_{0}+\alpha_{1} \frac{1}{T A_{i, t-1}}+\alpha_{2} \frac{S_{i, t-1}}{T A_{i, t-1}}+\boldsymbol{\varepsilon}_{i t}
$$

$\boldsymbol{A B N A C C J}=$ abnormal accruals which is measured by the estimated residual from the following regression:

$$
\frac{T A C C_{i t}}{T A_{i, t-1}}=\alpha_{0}+\alpha_{1} \frac{1}{T A_{i, t-1}}+\alpha_{2} \frac{\triangle S_{i t}-\triangle R E C_{i t}}{T A_{i, t-1}}+\alpha_{3} \frac{P P E_{i, t}}{T A_{i, t-1}}+\varepsilon_{i t}
$$

$\boldsymbol{P P E}=$ property, plant, and equipment 
$S I Z E=$ the logarithm of the market value of equity at the beginning of the year

$\boldsymbol{R O A}=$ net income before extraordinary items scaled by lagged total assets

The rest of variables are as previously defined.

**Panel B presents correlations among the variables used in Equation (5) for the whole sample of 23524 observations. Pearson (Spearman) correlation coefficients are presented in the lower (upper) triangle. Bolded coefficients are significant at 0.1 level. 


\section{Table 3. Comparison of Suspect Firms with the Rest of Sample}

$\begin{array}{lcccc} & \begin{array}{c}\text { ABNCFO } \\ \mathrm{n}=23.514\end{array} & \begin{array}{c}\text { ABNPC } \\ \mathrm{n}=22.646\end{array} & \begin{array}{c}\text { ABNDE } \\ \mathrm{n}=22.884\end{array} & \begin{array}{c}\text { ABNACCJ } \\ \mathrm{n}=23.397\end{array} \\ \text { Intercept } & 0.0061^{* *} & 0.0024 & -0.0140^{* * *} & -0.0046^{* *} \\ & (2.38) & (0.54) & (-3.11) & (-2.07) \\ \text { SIZE } & 0.0017 & -0.0047^{* *} & 0.0032 & -0.0220^{* * * *} \\ & (0.96) & (-2.08) & (1.39) & (-10.06) \\ \text { MTB } & 0.0004^{*} & -0.0011^{* * *} & 0.0014^{* * *} & -0.0003 \\ & (1.67) & (-3.04) & (3.23) & (-0.79) \\ \text { ROA } & 0.3756^{* * *} & -0.1570^{* * *} & -0.2644 * * * & 0.3568^{* * *} \\ & (14.65) & (-7.79) & (-13.54) & (10.17) \\ \text { SUSPECT } & -0.0145^{* * *} & -0.0069^{* *} & 0.0326^{* * *} & 0.0109 * * * \\ & (-7.44) & (-2.16) & (9.77) & (5.98) \\ \text { Adj. } \boldsymbol{R}^{2} \text { (\%) } & 34.59 & 3.36 & 9.43 & 34.59\end{array}$

This table reports the coefficients from the following regression:

$$
E M M_{t}=\alpha+\beta_{1}(S I Z E)_{t-1}+\beta_{2}(M T B)_{t-1}+\beta_{3}(R O A)_{t}+\beta_{4}(S U S P E C T)_{t}+\sum_{j} \beta_{5, j} Y \text { ear }_{j}+\varepsilon_{t}
$$

The above model is run separately for each model and EMM denotes earnings management measures including abnormal cash flow from operations, abnormal production costs, abnormal discretionary expenses and abnormal accruals using Jones method. T statistics, reported in parentheses, are generated using Newey-West procedure to correct for autocorrelation and heteroskedasticity.

Variables are as previously defined.

$*, * *, * * *$ represent that the coefficient is significant at $10 \%, 5 \%$, and $1 \%$, respectively. 


\section{Table 4. First-Step Heckman Results}

\section{Intercept}

$M T B_{t-1}$

$\mathrm{ROA}_{t}$

$S I Z E_{t-1}$

$\operatorname{NOS}_{t}$

Year indicators

Number of observations

Pseudo $R^{2}(\%)$
Suspect $_{\text {t }}$

$1.9028 * * *$

(23.40)

$0.0045 * * *$

(4.64)

$-0.1834 * * *$

$(-5.26)$

$-0.4436 * * *$

$(-31.74)$

$0.3607 * * *$

(17.91)

Included

22,822

6.05

This table presents the results of the following probit regression model as the first step of the Heckman method using the whole sample from 2002 to 2011. Z statistics are reported in parentheses.

$$
\text { Suspect }_{\mathrm{t}}=\alpha+\beta_{1}(\mathrm{SIZE})_{\mathrm{t}-1}+\beta_{2}(\mathrm{MTB})_{\mathrm{t}-1}+\beta_{3}(\mathrm{ROA})_{\mathrm{t}}+\beta_{4}(\mathrm{NOS})_{\mathrm{t}}+\sum_{\mathrm{j}} \beta_{5, \mathrm{j}} \text { Year }_{\mathrm{j}}+\varepsilon_{\mathrm{t}}
$$

$\mathrm{NOS}_{\mathrm{t}}$ is the log of number of shares outstanding in year $t$. All other variables are as previously defined. Variables are winsorised at $1 \%$ tails to reduce the impact of outliers.

$*, * *, * * *$ represent that the coefficient is significant at $10 \%, 5 \%$, and $1 \%$, respectively. 
Table 5. Descriptive Analysis for Costs of Earnings Management

\section{Panel A*: Summary Statistics}

\begin{tabular}{|c|c|c|c|c|c|}
\hline Variable & Mean & $\underline{\text { SD }}$ & $\underline{25 \%}$ & $\underline{50 \%}$ & $\underline{75 \%}$ \\
\hline $\mathbf{R A M}_{t}$ & -0.0012 & 0.2318 & -0.0954 & 0.0028 & 0.1060 \\
\hline $\mathbf{A M}_{t}$ & 0.0000 & 0.1511 & -0.0383 & 0.0059 & 0.0478 \\
\hline $\mathbf{M S}_{t-1}$ & 0.0103 & 0.0493 & 0.0000 & 0.0003 & 0.0027 \\
\hline $\mathrm{Z}_{-} \mathrm{SCORE}_{t}$ & 4.2536 & 22.1108 & 0.9959 & 2.4361 & 4.6235 \\
\hline $\mathrm{IOWN}_{t-1}$ & 28.9032 & 22.5047 & 11.0000 & 24.0000 & 43.0000 \\
\hline $\mathrm{MTR}_{t}$ & 29.4613 & 25.4185 & 15.3700 & 30.8400 & 37.6800 \\
\hline BIG_FOUR $_{t}$ & 0.6317 & 0.4823 & 0.0000 & 1.0000 & 1.0000 \\
\hline $\mathrm{NOA}_{t-1}$ & 3.5369 & 22.7191 & 0.4199 & 0.8361 & 1.9922 \\
\hline $\mathrm{OC}_{t}$ & 241.4886 & 1923.3920 & 78.5479 & 128.9196 & 206.3355 \\
\hline $\mathrm{ROA}_{t}$ & -0.0470 & 0.2956 & -0.0557 & 0.0299 & 0.0767 \\
\hline $\operatorname{SIZE}_{t}$ & 8.2209 & 0.9784 & 0.0556 & 8.2469 & 8.9028 \\
\hline $\mathrm{MTB}_{t}$ & 3.5423 & 17.2211 & 0.9287 & 1.6860 & 3.1077 \\
\hline
\end{tabular}

\section{Panel B**: Pearson (Lower Triangle) and Spearman (Upper Triangle) Correlations}

\begin{tabular}{|c|c|c|c|c|c|c|c|c|c|c|c|c|}
\hline & $\underline{\mathbf{R A M}}_{4}$ & $\underline{\mathrm{AM}_{4}}$ & $\underline{\mathbf{M S}_{t_{1}}}$ & Z SCORE & $\underline{I O W N}_{t-1}$ & $\underline{\text { MTR }_{t}}$ & BIG FOUR, & $\mathrm{NOA}_{t}$ & $\underline{\mathbf{O C}_{t}}$ & $\underline{\text { ROA }_{4}}$ & $\underline{\text { SIZE }_{t}}$ & $\underline{\text { MTB }_{t}}$ \\
\hline $\mathbf{R A M}_{t}$ & & 0.17 & 0.12 & -0.16 & 0.02 & 0.04 & -0.00 & -0.04 & -0.09 & -0.24 & -0.02 & -0.23 \\
\hline $\mathbf{A M}_{t}$ & 0.06 & & -0.11 & -0.03 & 0.02 & -0.09 & -0.15 & -0.01 & 0.10 & 0.06 & -0.14 & -0.06 \\
\hline $\mathbf{M S}_{t-1}$ & 0.00 & 0.00 & & -0.15 & 0.05 & 0.18 & 0.45 & -0.12 & -0.20 & -0.08 & 0.63 & -0.10 \\
\hline $\mathrm{Z}_{-}$SCORE $_{t}$ & 0.00 & -0.01 & -0.02 & & 0.04 & 0.09 & -0.03 & -0.05 & -0.01 & 0.32 & 0.07 & 0.36 \\
\hline $\operatorname{IOWN}_{t-1}$ & -0.01 & 0.02 & -0.01 & -0.01 & & -0.00 & -0.04 & -0.01 & 0.02 & -0.05 & -0.10 & -0.02 \\
\hline MTR $_{t}$ & 0.05 & -0.09 & 0.04 & 0.02 & 0.02 & & 0.06 & -0.03 & -0.09 & -0.19 & 0.06 & -0.10 \\
\hline BIG_FOUR $_{t}$ & -0.00 & -0.03 & 0.45 & -0.03 & -0.04 & 0.06 & & 0.08 & -0.03 & -0.03 & 0.60 & 0.09 \\
\hline $\mathrm{NOA}_{t-1}$ & 0.02 & -0.02 & -0.02 & 0.02 & -0.02 & 0.01 & 0.08 & & 0.31 & -0.08 & 0.18 & -0.04 \\
\hline $\mathrm{OC}_{t}$ & 0.01 & -0.01 & -0.01 & 0.00 & 0.01 & -0.01 & -0.03 & 0.13 & & -0.07 & -0.04 & -0.08 \\
\hline $\mathbf{R O A}_{t}$ & -0.17 & 0.38 & 0.07 & -0.00 & 0.12 & -0.21 & -0.03 & -0.08 & -0.08 & & 0.05 & 0.24 \\
\hline $\operatorname{SIZE}_{t}$ & -0.02 & -0.1 & 0.27 & 0.08 & 0.00 & 0.07 & 0.60 & -0.01 & -0.02 & 0.021 & & 0.27 \\
\hline MTB $_{t}$ & -0.02 & -0.04 & -0.01 & 0.05 & -0.01 & -0.01 & 0.09 & -0.01 & 0.00 & -0.07 & 0.03 & \\
\hline
\end{tabular}

* Panel A reports the mean, standard deviation, and quartiles of the variables used in Equation (7) and Equation (8).

Variable definitions:

$\mathrm{RAM}_{t}=$ The total amount of activities manipulation in year $t$ computed as the sum of abnormal discretionary expenses multiplied by minus one and abnormal production costs.

$\mathrm{AM}_{t}=$ Accruals management captured by abnormal accruals in year $t$.

$\mathrm{MS}_{t-1}=$ Market share of a firm at the beginning of the period measured as the ratio of a firm's sales revenue to the total sales of its corresponding industry using two-digit SIC codes.

$\mathrm{Z}_{-} \mathrm{SCORE}_{t}=$ Altman's Z-score (Altman, 1968) at the beginning of the period.

IOWN $_{t-1}=$ Institutional ownership captured by the percentage of institutional ownership at the beginning of the period.

$\mathrm{MTR}_{t}=$ Marginal tax rate proxied by the effective tax rate in year $t$.

BIG_FOUR $_{t}=$ An indicator variable that takes 1 in the presence of Big Four Auditors and 0 otherwise. 
$\mathrm{NOA}_{t-1}=$ Net operating assets at the beginning of the period.

$\mathrm{OC}_{t}=$ The length of operating cycle.

Other variables are as previously defined.

**Panel B presents correlations among the variables used in Equation (7) and Equation (8) for firms suspected of income-decreasing manipulation $(\mathrm{n}=2,973)$. Pearson (Spearman) correlation coefficients are presented in the lower (upper) triangle. Bolded coefficients are significant at 0.1 level. 


\section{Table 6. Second-Step Heckman Results}

RAM

$\underline{(n=2.973)}$

Intercept

0.04474

(0.89)

AM

$\underline{(n=2.973)}$

Costs of Real Activities Manipulation:

$\mathrm{Z}_{-} \mathrm{SCORE}_{\boldsymbol{t}}$

$-0.0002 *$

$0.1375 * * *$

(13.17)

$\mathbf{M S}_{t-1}$

$(-1.66)$

$-0.0002$

0.0264

$(-1.25)$

$0.0463 * * *$

$\operatorname{IOWN}_{t-1}$

$0.0001 * * *$

MTR $_{t}$

$-0.0002$

$(-1.23)$

$-0.0004 * * *$

Costs of Accruals Management:

BIG_FOUR $_{t}$

$-0.0091$

$(-10.43)$

NOA $_{t-1}$

$-0.0208 * * *$

$0.0034 *$

$0.0033 * * *$

(2.03)

(6.41)

$\mathrm{OC}_{t}$

$-0.0001 * * *$

Control Variables:

SIZE $_{t}$

$-0.0131$

$(-1.42)$

$-0.0001$

$(-0.31)$

$\mathbf{R O A}_{t}$

$-0.9475 * * *$

(-14.62)

$-0.0120 * * *$

$(-6.44)$

$-0.0004 * * *$

$(-4.49)$

$-0.0639 * * *$

EXP_RAM $_{t}$

$-0.2052 * * *$

$(-13.49)$

UNEXP_RAM $_{t}$

$0.0720 * * *$

(18.29)

$\operatorname{IMR}_{t}$

$0.1236 * * *$

0.0005

\section{Year Indicators}

Adj. $R^{2}(\%)$

\begin{tabular}{cc}
$(2.76)$ & $(0.06)$ \\
\hline Included & Included \\
7.17 & 12.00
\end{tabular}

This table reports the coefficients from the following regressions:

$\mathrm{RAM}_{t}=\beta_{0}+\sum_{k} \beta_{1, k} R M_{-}$COST $_{k, t}+\sum_{l} \beta_{2, l}$ AM $_{-} \operatorname{COST}_{l, t}+\sum_{m} \beta_{3, m} \operatorname{CONTROL}_{m, t}+u_{t}$

$\mathrm{AM}_{t}=\beta_{0}+\sum_{k} \gamma_{1, k} A M_{-} \operatorname{COST}_{k, t}+\sum_{l} \gamma_{2, l} R A M_{-} \operatorname{COST}_{l, t}+\gamma_{3, n}$ EXP_RAM $_{t}+\gamma_{4, p}$ UNEXP_RAM $_{t}+$ $\sum_{m} \gamma_{5, m} \operatorname{CONTROL}_{m, t}+v_{t}$

RAM_COST indicates the costs of involvement in manipulation of activities which includes market share $\left(\mathrm{MS}_{t-1}\right)$, financial health $\left(\mathrm{Z}_{-} \mathrm{SCORE} t\right)$, institutional ownership $\left(\mathrm{IOWN}_{t-1}\right)$ and marginal tax rate $\left(\mathrm{MTR}_{t}\right)$. AM_COST indicates the costs of accruals management including presence of Big Four Auditors (BIG_FOUR ${ }_{t}$ ), net operating assets at the beginning of the period $\left(\mathrm{NOA}_{t-1}\right)$ and the length of operating cycle $\left(\mathrm{OC}_{t}\right)$. EXP_RAM $_{t}$ is the predicted level of activities manipulation and UNEXP_RAM ${ }_{t}$ is the residual both extracted from Equation (7). IMR ${ }_{t}$ is the inverse Mills ratio extracted from the Equation (7). T statistics are reported in parentheses. All other variables are as previously defined.

$*, * *, * * *$ represent that the coefficient is significant at $10 \%, 5 \%$, and $1 \%$, respectively. 


\section{Table 7. Alternative Performance Thresholds}

\begin{tabular}{|c|c|c|c|c|}
\hline PT & $\begin{array}{c}\text { ABNCFO } \\
\underline{n}=23,514\end{array}$ & $\begin{array}{l}\text { ABNPC } \\
\underline{n}=22,646 \\
\end{array}$ & $\begin{array}{l}\text { ABNDE } \\
\underline{n}=22.884 \\
\end{array}$ & $\begin{array}{c}\text { ABNACCJ } \\
\underline{n}=23,397\end{array}$ \\
\hline $20 \%$ & $\begin{array}{c}-0.0055 * * \\
(-2.38)\end{array}$ & $\begin{array}{c}-0.0122 * * * \\
(-3.85)\end{array}$ & $\begin{array}{c}0.0293 * * * \\
(9.41)\end{array}$ & $\begin{array}{c}0.0014 \\
(0.52)\end{array}$ \\
\hline $30 \%$ & $\begin{array}{c}-0.0093 * * * \\
(-4.47)\end{array}$ & $\begin{array}{c}-0.0123 * * * \\
(-3.91)\end{array}$ & $\begin{array}{c}0.0318 * * * \\
(10.11)\end{array}$ & $\begin{array}{c}0.0046^{*} \\
(2.16)\end{array}$ \\
\hline $40 \%$ & $\begin{array}{c}-0.0124 * * * \\
(-6.36)\end{array}$ & $\begin{array}{c}-0.0079 * * \\
(-2.52)\end{array}$ & $\begin{array}{c}0.0315 * * * \\
(9.76)\end{array}$ & $\begin{array}{c}0.0083 * * * \\
(4.38)\end{array}$ \\
\hline $50 \%$ & $\begin{array}{c}-0.0145 * * * \\
(-7.44)\end{array}$ & $\begin{array}{c}-0.0069^{* *} \\
(-2.16)\end{array}$ & $\begin{array}{c}0.0326 * * * \\
(9.77)\end{array}$ & $\begin{array}{c}0.0109 * * * \\
(5.98)\end{array}$ \\
\hline $60 \%$ & $\begin{array}{c}-0.0162 * * * \\
(-8.13)\end{array}$ & $\begin{array}{c}-0.0071^{* *} \\
(-2.19)\end{array}$ & $\begin{array}{c}0.0334 * * * \\
(9.70)\end{array}$ & $\begin{array}{c}00.0130 * * * \\
(6.89)\end{array}$ \\
\hline $70 \%$ & $\begin{array}{c}-0.0178 * * * \\
(-8.60)\end{array}$ & $\begin{array}{c}-0.0072 * * \\
(-2.16)\end{array}$ & $\begin{array}{c}0.0332 * * * \\
(9.32)\end{array}$ & $\begin{array}{c}0.0155 * * * \\
\quad(7.65)\end{array}$ \\
\hline $80 \%$ & $\begin{array}{c}-0.0187 * * * \\
(-8.57)\end{array}$ & $\begin{array}{c}-0.0062 * \\
(-1.82)\end{array}$ & $\begin{array}{c}0.0333 * * * \\
(9.07)\end{array}$ & $\begin{array}{c}0.0165 * * * \\
(7.49)\end{array}$ \\
\hline $90 \%$ & $\begin{array}{c}-0.0195 * * * \\
(-8.54)\end{array}$ & $\begin{array}{c}-0.0058^{*} \\
(-1.67)\end{array}$ & $\begin{array}{c}0.0342 * * * \\
\quad(9.02)\end{array}$ & $\begin{array}{c}0.0174 * * * \\
\quad(7.34)\end{array}$ \\
\hline $100 \%$ & $\begin{array}{c}-0.0200 * * * \\
(-8.44)\end{array}$ & $\begin{array}{c}-0.0046 \\
(-1.28)\end{array}$ & $\begin{array}{c}0.0339 * * * \\
(8.69)\end{array}$ & $\begin{array}{l}0.0183 * * * \\
\quad(7.24)\end{array}$ \\
\hline $150 \%$ & $\begin{array}{c}-0.0205 * * * \\
(-7.32)\end{array}$ & $\begin{array}{c}-0.0051 \\
(-1.3)\end{array}$ & $\begin{array}{c}0.0345 * * * \\
(8.14)\end{array}$ & $\begin{array}{l}0.0205 * * * \\
\quad(6.31)\end{array}$ \\
\hline $200 \%$ & $\begin{array}{c}0.0209 * * * \\
(-6.60)\end{array}$ & $\begin{array}{c}-0.0062 \\
(-1.56)\end{array}$ & $\begin{array}{c}0.0363 * * * \\
(8.42)\end{array}$ & $\begin{array}{c}0.0213 * * * \\
(5.59)\end{array}$ \\
\hline $250 \%$ & $\begin{array}{c}-0.0217 * * * \\
(-6.40)\end{array}$ & $\begin{array}{c}-0.0069^{*} \\
(-1.65)\end{array}$ & $\begin{array}{c}0.0381 * * * \\
(8.50)\end{array}$ & $\begin{array}{c}0.0224 * * * \\
(5.31)\end{array}$ \\
\hline
\end{tabular}

This table reports the coefficients on SUSPECT from the following regression:

$$
E M M_{t}=\alpha+\beta_{1}(S I Z E)_{t-1}+\beta_{2}(M T B)_{t-1}+\beta_{3}(N I)_{t}+\beta_{4}(S U S P E C T)_{t}+\sum_{j} \beta_{5, j} Y_{e a r}+\varepsilon_{t}
$$

The above model is run separately for each model. EMM denotes earnings management measures including abnormal cash flow from operations, abnormal production cost, abnormal discretionary expenses, and abnormal accruals using Jones method. T statistics, reported in parentheses, are generated using Newey-West procedure to correct for autocorrelation and heteroskedasticity.

Variable definitions:

$\boldsymbol{P T}=$ Performance threshold (i.e. the percentage by which the earnings of the first three quarters of the current year are to be higher compared to that of the last year) for selecting firms as suspected of income-decreasing manipulation.

All other variables are as previously defined. 


\section{Table 8. Loss Suspect Firms versus Profit Suspect Firms}

\begin{tabular}{|c|c|c|c|c|c|c|c|c|}
\hline & \multicolumn{2}{|c|}{$\begin{array}{c}\text { ABNCFO } \\
n=23,514\end{array}$} & \multicolumn{2}{|c|}{$\begin{array}{l}\text { ABNPC } \\
n=22,646\end{array}$} & \multicolumn{2}{|c|}{$\begin{array}{l}\text { ABNDE } \\
n=22,884\end{array}$} & \multicolumn{2}{|c|}{$\begin{array}{c}\text { ABNACCJ } \\
n=23,397\end{array}$} \\
\hline & Loss & Profit & Loss & Profit & Loss & Profit & Loss & Profit \\
\hline Intercept & $\begin{array}{c}0.0041 \\
(1.58)\end{array}$ & $\begin{array}{c}0.0002 \\
(0.08)\end{array}$ & $\begin{array}{l}-0.0008 \\
(-0.20)\end{array}$ & $\begin{array}{c}0.0024 \\
(0.56)\end{array}$ & $\begin{array}{l}-0.0026 \\
(-0.61)\end{array}$ & $\begin{array}{c}-0.0090 * * \\
(-2.06)\end{array}$ & $\begin{array}{c}-0.0046^{*} \\
(-1.96)\end{array}$ & $\begin{array}{l}0.0017 \\
(0.65)\end{array}$ \\
\hline SIZE & $\begin{array}{c}0.0013 \\
(0.81)\end{array}$ & $\begin{array}{c}0.0031^{*} \\
(1.65)\end{array}$ & $\begin{array}{c}-0.0039 * \\
(-1.78)\end{array}$ & $\begin{array}{c}-0.0044^{*} \\
(-1.94)\end{array}$ & $\begin{array}{l}0.0012 \\
(0.54)\end{array}$ & $\begin{array}{c}0.0011 \\
(0.48)\end{array}$ & $\begin{array}{c}-0.0209 * * * \\
(-11.98)\end{array}$ & $\begin{array}{c}-0.0232 * * * \\
(-10.04)\end{array}$ \\
\hline МТВ & $\begin{array}{c}0.0004 * \\
(1.71)\end{array}$ & $\begin{array}{c}0.0004 \\
(1.59)\end{array}$ & $\begin{array}{c}-0.0011 * * * \\
(-3.06)\end{array}$ & $\begin{array}{c}-0.0011^{* * * *} \\
(-3.05)\end{array}$ & $\begin{array}{l}0.0014 * * * \\
(3.26)\end{array}$ & $\begin{array}{c}0.0014 * * * \\
(3.29)\end{array}$ & $\begin{array}{c}-0.0002 \\
(-0.84)\end{array}$ & $\begin{array}{c}-0.0002 \\
(-0.74)\end{array}$ \\
\hline ROA & $\begin{array}{c}0.6325 * * * \\
(13.23)\end{array}$ & $\begin{array}{c}0.3760 * * * \\
(13.89)\end{array}$ & $\begin{array}{c}-0.1561 * * * \\
(-7.15)\end{array}$ & $\begin{array}{c}-0.1526 * * * \\
(-7.31)\end{array}$ & $\begin{array}{c}-0.2569 * * * \\
(-12.10)\end{array}$ & $\begin{array}{c}-0.2773 * * * \\
(-13.80)\end{array}$ & $\begin{array}{l}0.3718^{* * * *} \\
(9.86)\end{array}$ & $\begin{array}{c}0.3594 * * * \\
(9.71)\end{array}$ \\
\hline SUSPECT & $\begin{array}{c}0.0307 * * * \\
(4.76)\end{array}$ & $\begin{array}{l}-0.0007 \\
(-0.19)\end{array}$ & $\begin{array}{c}0.0024 \\
(0.37)\end{array}$ & $\begin{array}{c}-0.0103 * * \\
(-2.33)\end{array}$ & $\begin{array}{c}0.0187 * * * \\
(2.69)\end{array}$ & $\begin{array}{c}0.0309 * * * \\
(7.54)\end{array}$ & $\begin{array}{c}0.0341 * * * \\
(4.10)\end{array}$ & $\begin{array}{c}-0.0058^{*} \\
(-1.96)\end{array}$ \\
\hline $\operatorname{Adj} . R^{2}(\%)$ & 34.77 & 34.42 & 3.34 & 3.38 & 9.06 & 9.30 & 34.07 & 33.57 \\
\hline
\end{tabular}

This table reports the coefficients on SUSPECT from the following regression separately for profit making $(\mathrm{n}=$ 6003) and loss making $(\mathrm{n}=3327)$ suspect firms:

$$
E M M_{t}=\alpha+\beta_{1}(S I Z E)_{t-1}+\beta_{2}(M T B)_{t-1}+\beta_{3}(R O A)_{t}+\beta_{4}(S U S P E C T)_{t}+\sum_{j} \beta_{5, j} Y_{e a r_{j}}+\varepsilon_{t}
$$

The above model is run separately for each model. EMM denotes earnings management measures including abnormal cash flow from operations, abnormal production cost, abnormal discretionary expenses, and abnormal accruals using Jones method. Newey-West procedure is used to correct for autocorrelation and heteroskedasticity.

Variable are as previously defined.

*,**,*** represent that the coefficient is significant at $10 \%, 5 \%$, and $1 \%$, respectively. 